\title{
АНАЛОГИЧНЫЙ ПРОМЫШЛЕННОСТИ ТРУД В РАБСКИЙ ТРУД В ТЕКСТИЛЬНОЙ ПРОМЫШЛЕННОСТИ БРАЗИЛИИ
}

\section{ОРИГИНАЛЬНАЯ СТАТЬЯ}

NETO, Dalk Dias Salomão ${ }^{1}$, SOUSA, Nicole Moreira Faria² ${ }^{2}$ DENDASCK, Carla Viana $^{3}$, FECURY, Amanda Alves ${ }^{4}$, OLIVEIRA, Euzébio de ${ }^{5}$, DIAS, Claudio Alberto Gellis de Mattos ${ }^{6}$

NETO, Dalk Dias Salomão. Эт аль. Аналогичный промышленности труд в рабский труд в текстильной промышленности Бразилии. Revista Científica Multidisciplinar Núcleo do Conhecimento. Год 06, эд. 05, Vol. 13, стр. 28-46. Май 2021 года. ISSN: 2448-0959, Ссылка доступа: https://www.nucleodoconhecimento.com.br/социальные-науки/текстильнойпромышленности , DOI: 10.32749/nucleodoconhecimento.com.br/ru/86628

\section{СВОДКА}

Институт рабства присутствует в человечестве с самого начала существования человека. Рабство в Бразилии поддерживало экономику на протяжении веков. Миллионы африканцев были вывезены со своей родины и помещены в унизительные условия жизни и работы. Процесс отмены рабства занимает много времени и постепенно. Существовали веков много борьбы и страданий для мира,

\footnotetext{
${ }^{1}$ Адвокат, бакалавр права (СЕАР - Центр высшего образования Атара́), специалист по трудовому праву и трудовому процессу в учебном заведении Damásio.

${ }^{2}$ Адвокат, бакалавр права (CEAP - Центр высшего образования Атара́), специалист по гражданскому процессуальному праву в учреждении Damásio Educacional.

${ }^{3}$ Богослов, кандидат медицинских наук в области клинического психоанализа. Он работает в течение 15 лет с научной методологией (метод исследования) в руководстве научного производства магистра и докторантуры. Специалист по исследованиям рынка и исследованиям, ориентированным на здоровье. ${ }^{4}$ Биомедицинская, phD в области тропических болезней, профессор и исследователь медицинского курса кампуса Масара́, Федеральный университет Amapá (UNIFAP), проректор по исследованиям и аспирантуре (PROPESPG) Федерального университета Amapá (UNIFAP).

${ }^{5}$ Биолог, доктор философии в области тропических болезней, профессор и исследователь курса физкультуры, Федеральный университет Pará (UFPA).

${ }^{6}$ Биолог, кандидат теоретических и летных исследований, профессор и исследователь курса химической степени Института базового, технического и технологического образования Amapá (IFAP) и Высшей программы профессионального и технологического образования (PROFEPT IFAP).

RC: 86628

Ссылка доступа: https://www.nucleodoconhecimento.com.br/социальныенауки/текстильной-промышленности
} 
чтобы начать понимать зло, что рабство представляет. Даже после отмены рабства было принято видеть работника, оказавогося в ловушке на местах из-за долгов, или по законам, наделя работодателей полномочиями по отношению к работнику. Целью этого исследования было проанализировать условия труда, аналогичные рабу в бразильской текстильной промышленности. Она проводилась с помощью библиографического обзора и качественного анализа. Благодаря своей новой одежде современный рабский труд стал на некоторое время невидимым. Факторы, которые делают возможным совершение этого преступления, даже если в настоящее время, это в основном связано с штативом: безнаказанность, бедность и прибыль. Положение в условиях нищеты наиболее нуждающихся селения вынуждает их проходить виды работ в нечеловеческих условиях. Эти текстильные работники в основном являются иммигрантами из соседних, слаборазвитых стран Латинской Америки. Бразилия была одной из первых стран в мире, признавающих этот вид работы, и что совместно с Международной организацией труда (ОІТ) и правительственными образованиями, стремятся бороться с такой преступной практикой на своей территории.

Ключевые слова: Рабство, Законодательство, Борьба, Промышленность.

\section{ЗНАКОМСТВО}

Институт рабства присутствует в человечестве с самого начала существования человека. Хотя на протяжении всей истории оно представляло различные значения, формы и цели, рабство всегда было отмечено господством друг друга (Mota e Ramos, 1999)

Для Oliveira (2011) отношения между мужчинами начались в доисторической фразе, из-за нестабильных условий жизни и необходимости охоты, рыбалки и сбора фрруктов. И именно благодаря обмену опытом и сотрудничеству между индивидуумами возникли первые племена. 
Институт рабства сопровождает человека с самого начала человеческой расы, как уже было сказано, имея доказательства его существования в различные моменты человечества и в бесчисленных формах. Например, в священной Библии (основной книге христиан) мы находим многочисленные случаи рабства, приведенные во всех Евангелиях. Рабство в то время основывалось на рабстве долгов или работе, вызванной, в частности, подчинением проигравшего победителем (Oliveira, 2011).

С использованием рабства для тяжелых рабочих мест, такие люди, как греки сумели развивать фрилософию и искусство, как никто другой. В связи с коммерческим производством произошло значительное расширение кустарного и сельскохозяйственного производства, ориентированного на экспортную и импортную торговлю (Oliveira, 2011).

Для Silva (2010), как и в Греции, Рим использовал рабский труд, и именно в период империи рабство достигло пика, достигнув в общей сложности $30 \%$ римского общества.

В Риме было много способов стать рабом, как правило, каждый сын рабыни был также рабом. Другим способом порабощения кого-либо была война, когда заключенных принуждали к принудительной работе, рабство также использовалось как способ наказания отдельных лиц, например, в случае дезертирства армии или просрочки долгов (Silva, 2010).

Общество средневековья было сформировано феодальными лордами, духовенством и слугами. В этот период рабство не было основным средством труда, будучи подменой слуг рабов, страдающих ужасными условиями жизни и работы (Silva, 2010).

Хотя слуги не считались объектами, их правовое положение не так сильно отличалось от рабов, поскольку к ним относились как к простому приуготовию земли, страдали от навязывания личного распоряжения, не имея права 
приходить и уходить гарантированно и даже запрет на брак без разрешения (Silva, 2010).

Привлечение внимания к нашей стране важно отметить, что рабство присутствовало в исторической эволюции этой великой части земли. Первоначально известный как Santa Cruz de Cabrália, а затем из Бразилии, он был колонизирован португальцами, которые, когда они прибыли сюда в 1500 году, принес с собой крупномасштабное рабство, начиная с туземцев, тупи и гуарани в основном, а затем чернокожих африканцев (Silva, 2010).

Чтобы преуспеть в поисках сырья для мегаполиса, португальцы начали колонизацию, используя рабство в качестве добывающей базы. Во-первых, они использовали родной труд, делая бартер с ними, что, в обмен на специи и металлы, оставили индейцам предметы неактуальной ценности, такие как зеркала и гребни (Oliveira, 2011).

Отношения португальской короны и туземцев поначалу были вполне мирными, однако после того, как португальцы решили оккупировать территорию для развития экономической эксплуатации, отношения изменились. С тех пор поселенцы начали изгонять туземцев со своих земель и подчинить их рабскому труду, который страдал от фризической эксплуатации и новых болезней, вызванных белым человеком (Gorender, 1985).

Однако коренные народы долго страдали от рабства, однако эта ситуация не длилась долго, учитывая ряд фракторов, замедляя эксплуатацию коренных народов, таких, как низкая плотность населения коренных народов; племена, которые стали неподразмы, когда они воспринимали свое порабощение; коренное население, которое в конечном итоге было уничтожено из-за эксплуатации и болезней, ранее неизвестных, а также защиты, полученной иезуитами (Campos, 2015).

Такая же защита, предоставленная коренным народам иезуитами, не была предоставлена чернокожим, поэтому их порабощение было практически RC: 86628

Ссылка доступа: https://www.nucleodoconhecimento.com.br/социальныенауки/текстильной-промышленности 
консенсусом между церковью и короной (Fausto, 2004). Одним из главных оправданий порабощения африканского чернокожего было то, что эта практика уже была распространена в Африке, также основанная на научных теориях, которые подтвердили неполноценность черной расы, потому что были продемонстрированы люди с низким интеллектом и эмоционально нестабильными, биологически предназначенными для субъективации, создавая одну из величайших форм предрассудков, когда-либо замеченных (Mattos, 2015).

Рабство в Бразилии поддерживало экономику на протяжении веков. Миллионы африканцев были вывезены со своей родины и помещены в унизительные условия жизни и работы. По данным (Soares, 1860), примерно 371615 рабов въехали в страну.

Первоначально рабский труд и бразильская экономика были сосредоточены в поле, в сельском хозяйстве, а точнее на плантациях сахарного тростника, расположенных на северо-востоке, будучи способом, найденным короной колонизации этой части "нового мира". Важно продемонстрировать, что в восемнадцатом веке, с прогрессивным расширением колонизации и открытием новых пространств во внутренних помещениях страны, был обнаружен большой горнодобывающий потенциал земель, создавая интенсивный рынок для добычи руды, таких как золото, где рабский труд позволил такой деятельности (Campos, 2015).

И именно такими темпами рабство негативно отметило не только мир, но и Бразилию. Единственным оправданием для импорта негра была работа. Они работали по часам подряд, от пятнадцати до восемнадцати часов в день, ежедневно страдали от ффизического насилия и психологии и рассматривались как объекты (Pinsky, 1992).

Процесс отмены рабства занимает много времени и постепенно. Существовали веков много борьбы и страданий для мира, чтобы начать понимать зло, что рабство представляет. Есть несколько важных моментов, которые представляют собой это изменение мысли: провозглашение независимости Соединенных $\mathrm{RC}: 86628$

Ссылка доступа: https://www.nucleodoconhecimento.com.br/социальныенауки/текстильной-промышленности 
Штатов, которое было основано на декларации прав человека; Французской революции 1789 года, возвеличив принципы свободы, равенства и братства. Стоит также отметить английскую революцию, которая с появлением машины показала, что производство может увеличиться даже при использовании бесплатной работы (Montenegro, 1997).

В связи с этим торговцам и производителям пришлось искать способ заменить рабский труд. Например, на кофейных плантациях рабский труд был заменен европейскими иммигрантами, в так называемой системе поселений (стимул бразильского государства), которые работали за вознаграждение, предусмотренное в проценте производства кофе (Silva, 2010).

Даже после отмены рабства было принято видеть работника, заключенного в тюрьму на местах из-за долгов, или законов, наделяющие работодателей полномочиями по отношению к работнику, посредством договорных обязательств, таких, как суровые наказания, такие, как арест работника, который был вдали от фрермы без какой-либо справедливой причины или который, оставаясь на имущество, отказался работать (Silva, 2010).

Таким образом, понятно, что отмена рабства в Бразилии, в соответствии с Законом Ауреа, на самом деле не освободить рабов, потому что существовало чрезвычайно расистское и предвзятое общество, что приводит к нынешней практике, аналогичной рабству

\section{ЦЕЛЬ}

Проанализировать условия труда, аналогичные рабу в бразильской текстильной промышленности.

\section{МЕТОД}

Исследование проводилось с библиографическим обзором и качественным анализом.

RC: 86628

Ссылка доступа: https://www.nucleodoconhecimento.com.br/социальныенауки/текстильной-промышленности 
По словам Lima и Mioto (2007): "[...]строительство исследовательского процесса, связанного с определением методологических процедур, которые будут направлять этот процесс, основано на наблюдении, которое сообщает несколько исследований".

Качественные исследования работают с ценностями, отношениями и взаимосвязью между процессами и явлениями, не измеряемые численно (Gerhardt e Silveira, 2009).

\section{РЕЗУЛЬТАТЫ И ОБСУЖДЕНИЕ}

\section{РАБСКИЙ ТРУД}

Существование рабского труда можно объяснить простым фрактом не преодоления старой рабской системы, из-за ее культурных корней на протяжении веков, даже после ее запрета. Кроме того, современное рабство основано на штативе: безнаказанность, жадность и нищета, становясь необходимыми не только для борьбы с этим преступлением, как и любой другой, но и для пересмотра нашей системы правосудия, моделей потребления и развития (Miranda e Oliveira, 2010).

Поэтому миру и его усилиям пока не удалось погасить рабский труд, продемонстрировав себя как трудная задача, особенно для культуры и отсутствия сострадания среди людей. Таким образом, и государства, и общество в целом должны быть бдительными в отношении такого рода ерунды.

\section{ЗАЩИТНЫЕ ПРИНЦИПЫ РАБОТЫ}

Правовые принципы определяются как набор стандартов поведения, которые представлены в правовой системе. Принципы, как и правила, являются нормами. Можно утверждать, что вся наука основана на принципах, поэтому закон не избегает этой нормы (Saraiva, 2012). 
По мнению Martins (2011, стр. 62) принципы формируют основы права, его основы, и принципы имеют гораздо более высокую степень абстракции, чем норма, и его применение в конкретных случаях (Martins, 2011).

Принципы объясняются двумя течениями, jusnaturalista (естественное право) правовой позитивизм, первый из которых ставит принципы выше позитивного права, таким образом, преобладающих в соответствии с законами. Во-вторых, принципы будут интеграторами закона, заполняя пробелы в нем (Nascimento, 2010).

Не избегая этой нормы, трудовое законодательство фрормируется на основе набора принципов и правил, которые направлены на обеспечение лучших условий труда для трудящихся посредством защиты.

Важно отметить принцип, который, хотя и не в сфрере труда, имеет первостепенное значение для правовой системы в целом, принципа достоинства человеческой человека. Этот принцип имеет присущую человеку моральную и духовную ценность, поэтому каждый человек поддерживается этой заповедью, и это является максимальным принципом демократического государства права.

Принцип защиты является самым широким и наиболее важным в трудовом праве. Этот принцип является одним из тех, которые направляют разрыв трудового законодательства, направленных на защиту самой слабой части в правовых отношениях, работник, который считает себя незащищенным по отношению к работодателю. Он стремится дать больше условий, чтобы часть гипосуфумических отношений, работник. Поэтому он предусматривает создание механизмов для сокращения неравенства между сторонами, предотвращение эксплуатации труда и обеспечение социального благополучия трудящихся (Saraiva, 2012).

Этот принцип обычно делится на три: "in dubio pro operário", что применения наиболее благоприятных стандартов и применения наиболее выгодных условий. Принцип "in dubio pro operário" гласит, что перед лицом двух или более $\mathrm{RC}: 86628$ Ссылка доступа: https://www.nucleodoconhecimento.com.br/социальныенауки/текстильной-промышленности 
жизнеспособных толкований необходимо выбрать наиболее благоприятный для работника, при условии, что он не противоречит четкому проявлению законодателя, равно как и не является запретительным вопросом. Принцип наиболее благоприятного правила гласит, что в случае конфликта между двумя или более правилами, применимыми в данном случае, следует сделать выбор в пользу того, который является более выгодным для работника. Наконец, принцип наиболее выгодного условия определяет благоухотворность более выгодных условий для работника, даже если существует императивная правовая норма, предусматривающая обратное (Saraiva, 2012; Mattos, 2015).

Трудовые права, как правило, необходимы работнику. Этот принцип крайне важен для защиты гипосуфиента, потому что часто работодатель, путем принуждения, обманывает или укрепляет работника, чтобы он решил против своей воли, отказав от уже заработанных прав (Rodriguez, 2015). То есть, как правило, трудовые права не могут быть отменены работником, например, нельзя отказываться от отпуска, если это происходит, то такое деяние будет считаться недействительным (Martinez, 2015).

Принцип Примата Реальности побуждает трудовые правосю отношения определяться ситуацией фракта, то есть тем, как оказывались услуги, независимо от названия, присвоенного им сторонами (Saraiva, 2012).

Наивным примером является то, что свидетельские показания доказаны в связи с нео предоставлением индивидуального рабочего оборудования (EPI), хотя имеются предостережения в отношении поставок. Поэтому ясно, что доказать достоверность фрактов можно через свидетелей, например, преобладая такие доказательства в письменном документе, если доказано подлинность показаний.

\section{ОБЩИЕ СООБРАЖЕНИЯ РАБСКОЙ РАБОТЫ}

Раньше рабы были замечены в качестве объектов, а сегодня уже нет. Однако, хотя в настоящее время они рассматриваются как люди, одобренные личностью, 
они по-прежнему подчинены унижающим достоинство условиям жизни и труда (Mattos, 2015).

Примечательно, что это называется «рабским трудом», так как сам рабский труд был потушен. Однако, несмотря на все усилия, такая практика рабства не исчезла полностью.

Существование рабского труда можно объяснить простым фрактом не преодоления старой рабской системы, из-за ее культурного укоренения на протяжении веков, несмотря на осуществление наеготового труда. Кроме того, современное рабство основано на штативе: безнаказанность, жадность и нищета, что делает необходимым, не только для борьбы с этим преступлением, как и любой другой, но пересмотреть нашу систему правосудия, структуры потребления и модели развития (Miranda e Oliveira, 2010).

Институт рабства в настоящее время имеет новую одежду, с несколькими конфессиями для рабского труда: современный рабский труд; работа в нечеловеческих условиях, долговое рабство, принудительный труд, чрезмерное трудовое обслуживание, новое рабство и другие, принудительный труд, унижающий достоинство труд среди прочих (Cristova e Goldschmidt, 2012).

Различные конфессии, из-за которого выше, не хватает консенсуса в отношении его концепции, а также критериев, используемых для его характеристики института. Из-за этого есть вариация элементов в ее концептуализации, а также в используемых терминах, чтобы сослаться на этот вид эксплуатации рабочего труда (Cristova e Goldschmidt, 2012).

Некоторые авторы уже позиционируют себя на эту тему, и не было единого понимания между мыслями. Тем не менее, было ясно, во всем том же чувство отвращения к этим бесчеловечным лечения людей, подвергая работника к нечеловеческим условиям (Brito Filho, 2004). 
Реальность порабощенного работника заключается в том, что тот, кто не имеет возможности выбор, не имея прав. Таких работников обычно заманивают в места, далекие от места работы, обещают хорошую работу, с подписанным портфолио, щедрым вознаграждением и другими льготами. Однако, когда работник прибывает на рабочее место, он в действительности полностью отличается от обещанного, большую часть времени он должен нести расходы на проезд, жилье и питание (Prado, 2005).

Термин "рабский труд" облегчает понимание со стороны более мирской общественности, поскольку он имеет характеристики, напоминающие концепции, принятые Международной организацией труда. Такая концепция была очень близка к "принудительному труду" (Audi, 2006).

С учетом этих понятий мы можем воспринимать, что работа, аналогичная рабу, существует, много раз, из-за гипосу недостаточности рабочих, которые, в поисках минимума для своих средств к существованию и своих семей, в конечном итоге оставляют в стороне свое собственное достоинство, подчиняясь унизительной работе (Campos, 2015).

Трудность в характеристике работы в рабских условиях не только в академической среде, она включает в себя государственных агентов, таких как судьи, прокуроры и сотрудники сотрудников органов трудовой полиции. Эта трудность имеет серьезные последствия, поскольку в конечном итоге препятствует характеристике и типизации акта, что затрудняет воспринятие самого преступления.

Поэтому, основываясь на вышеуказанных концепциях и исследованиях, можно определить работу в условиях, аналогичных состоянию раба, как осуществление человеческого труда с ограничением, в любой фрорме, которая может быть свободы работника, не имея его минимальных прав на защиту достоинства человека. 
Официальное признание рабской работы в Бразилии состоялось в 1995 году, несмотря на несколько жалоб в OIT (Международная организация труда) на протяжении многих лет. Несмотря на это усугубляющее обстоятельство, Бразилия была одной из первых стран в мире, которая на международном уровне заявила о существовании современного рабства (Miranda e Oliveira, 2010).

Как заявили в Министерстве труда и занятости (MTE), рабский труд является реальностью, очень присутствуют в стране, о чем свидетельствуют собственные данные MTE, которые показывают, что в период с 1995 по 2010 год 36759 рабочих были отстранены от рабских условий (Mte, 2018).

По данным Международной организации труда, основной причиной рабства является экономическая эксплуатация рабочих, которая, по оценкам, составляет около восьми миллионов человек, живущих в этих условиях в мире. В Бразилии, по данным бразильского правительства, предоставленным в результате исследований, проведенных Комиссией по пастбищной земле, около двадцати пяти тысяч человек работают в рабских условиях. На эту сумму самая высокая концентрация находится в северных и центрально-западных штатах, и 90\% от общего числа состоят из неграмотных, 90\% начали с эксплуатации детского труда, и 80\% даже не имеют свидетельства о рождении (Simón e Melo, 2007).

Бразилия, признанная ОІT, была одной из первых стран, которые узнали о рабском труде и боролись с нее. Таким образом, его криминализация произошла в соответствии со ст. 149 Уголовного кодекса Бразилии, которая впоследствии была изменена Законом No 10,803/2003 (Brasil, 1940; 2017) Очень важно подчеркнуть, что в Бразилии, в соответствии со статьей 149 СР, "рабский труд" является родом, с другими видами, такими как принудительный и унижающий достоинство труд (Brasil, 2017).

После внесения изменений в статью 149 СР законом № 10803 от 11 декабря 2003 года борьба с рабским трудом стала большим прогрессом, поскольку охарактеризовать такое правонарушение стало легче.

$\mathrm{RC}: 86628$

Ссылка доступа: https://www.nucleodoconhecimento.com.br/социальныенауки/текстильной-промышленности 
Рабская работа является родом, обладающим некоторыми видами. Для некоторых ученых в области эти виды варьируются, и может быть принудительный труд, исчерпывающий труд, унижающий достоинство труд и долг.

Simón e Melo (2007) использовать номенклатуру "работа выполняется в рабских условиях", делится на три вида: принудительный труд, труд в унижающих достоинство условиях и долгового рабства. Такие незаконные виды работы не имеют правовых последствий, поскольку они являются недействительными, а борьба с такой практикой, согласно бразильскому законодательству, осуществляется в соответствии с уголовным правом.

Ученый Greco (2008) утверждает, что рабский труд в настоящее время происходит, когда один человек заставляет другого выполнять принудительный труд, требуя исчерпывающих поездок, при условии работника к унижающим достоинство условиям, или ограничение его передвижения из-за задолженности контракт.

Silva (2010) также демонстрирует, что когерия работника, чтобы он не оставил работу может иметь несколько натур, моральных или психологических, как это происходит в угрозах психической целостности работника, а также фризической, и работник не может покинуть рабочее место, потому что в противном случае он понесет физическое наказание, часто с вооруженным наблюдением.

По словам Araújo Júnior (2006), работа в унижающих достоинство условиях характеризуется несоблюдением работодателем основных стандартов охраны труда и здоровья, которые не обеспечивают медицинское освидетельствование работника, не гарантируют индивидуального защитного оборудования (EPI) или места для защиты работников от непогоды, в дополнение к содержанию жилья без малейших гигиенических условий и без надлежащего питания.

Существует также исчерпывающая работа, известная как напряженная работа, в которой работник проверяется на условия труда за пределами сроков, RC: 86628

Ссылка доступа: https://www.nucleodoconhecimento.com.br/социальныенауки/текстильной-промышленности 
разрешенных законодательством, которые могут принести большой ущерб работнику. Исчерпывающий путь может быть концептуализирован как путешествие, которое выходит за рамки принципа достоинства человеческой человека. Такое напряженное путешествие означает не только преувеличенное количество часов, но и неадекватный темп (Campos, 2015).

Ученый Proner (2010) утверждает, что исчерпывающий рабочий день оказывает негативное влияние на работника, потому что лишает его моментов досуга и образования, социальной и семейной жизни, что может привести к психологическим и фризическим заболеваниям, так как он становится склонным к приобретению профессионального заболевания.

По словам Bales (2001) долговое рабство является современной формой эксплуатации человеческого труда, будучи наиболее распространенным в мире и особенно в Бразилии. Это условие возникает, когда человек стремится работать на другой из-за кредита по контракту. Трудовые договоры предлагаются с предполагаемых трудовых гарантий, как правило, в более географически отдаленных местах, на фрермах или заводах, однако, при прибытии на сайт реальность иная, обманутые работники в конечном итоге порабощены, обслуживая контракт только для того, чтобы обмануть работника и привести его к ошибке.

По словам Audi (2006), можно сделать вывод, что, несмотря на многочисленные представленные способы, все фрормы работы, аналогичные рабу, всегда имеют две общие черты: использование coerity и отрицание свободы.

\section{ФАКТОРЫ, СПОСОБСТВУЮЩИЕ РАБОТЕ РАБОВ В БРАЗИЛИИ}

В 1988 году был опубликован Lei Áurea, который отменил рабство в стране. Однако искоренить его было недейен, в силу ряда социальных фракторов, таких как дисквалификация рабочей силы «бывших рабов» (Cristova e Goldschmidt, 2012). 
Автор Monteiro (2011) отметил существенные фракторы для перманентности рабского труда в стране, определив их в штативе: безнаказанность, бедность и прибыль.

Что касается прибыли, то она относится к бенефициарам, которые используют рабский труд как способ получения высокой прибыли, легче, так как они не чувствуют себя обязанными соблюдать трудовое законодательство (Monteiro, 2011).

Что касается нищеты, то она является основной ответственностью за то, чтобы многие работники подчиниться работе в рабских условиях, поскольку они готовы согласиться даже с бесчеловечными предложениями с целью выбраться из крайней нищеты и поддержать свои семьи (Monteiro, 2011).

По данным Международной организации труда, основной причиной рабства является экономическая эксплуатация. И вместе с этой информацией, глобализация на рынках может быть основной причиной, так как она порождает большую конкуренцию, заставляя производителей / производителей согласиться на систему, производя по очень низким ценам (Cristova e Goldschmidt, 2012).

Что касается преобладающих фракторов существования рабского труда в сельских районах, Silva (2009) объясняет, что они влияют на бедный регион сельских рабочих, будучи областью с большим числом безработных, которые убеждены подрядчиком через ложные обещания, без официального трудового договора или каких-либо стандартов, установленных Консолидация трудового законодательства (CLT).

Что касается ранее объясненных знаний о том, что судебные решения, благоприятные для работодателей, способствуют поддержанию рабского труда в Бразилии, дополняет Silva (2009) считает, что нет строгого наказания в законодательстве, чтобы наказать тех, кто несет ответственность за эксплуатацию рабского труда. 
Таким образом, при отсутствии удовлетворительного законодательства, чувство производства безнаказанности, которая начинает передавать идею о том, что преступники могут продолжать с тем же преступным поведением, так как они не будут серьезными последствиями для их действий (Silva, 2009).

По для автора Damião (2014), причинами рабского труда в стране являются главным образом плохое распределение доходов и недостаточное образование. Таким образом, страдания, порождаемые несправедливым распределением доходов, как уже говорилось ранее, вынудляет трудягов подвергаться бесчеловечному отему рабского труда. С другой стороны, неудовлетворительное образование облегчает обман работников, так что они не в состоянии бороться за свои трудовые права.

В последние годы было создано несколько боевых механизмов, например, «грязный список» и национальные планы по искоренению рабского труда. Однако, несмотря на всю эту историю борьбы и надзора, в 2017 году в Бразилии по закону 13.467/17 произошла рефрорма трудового законодательства, которая привела к спаду в этой теме, тривиализуя практику преступности и препятствуя профилактике (Costa, 2015).

\section{ФОРМЫ БОРЬБЫ И ИСКОРЕНЕНИЯ РАБСКОГО ТРУДА KOHTEMПOPAHEO}

В Бразилии противостояние этого преступления приобрело силу в последние десятилетия, несмотря на задержку, с которыми столкнулась недавняя трудовая реформа. Известно, что существует бесчисленное множество случаев, когда люди живут в условиях, аналогичных рабству, которые обходят неустойчивый контроль государства (Oliveira, 2011).

Борьба и искоренение современного рабского труда гораздо сложнее, чем кажется, поскольку ситуация не решается просто путем вызрения работника из нестабильной ситуации и наказания правонарушителей. Что действительно должно быть сделано, так это изменение модели капиталистического развития, RC: 86628

Ссылка доступа: https://www.nucleodoconhecimento.com.br/социальныенауки/текстильной-промышленности 
которое в поисках прибыли прекращает жизнь целых семей (Miranda and Oliveira, 2010).

Существует несколько способов борьбы с рабским трудом, как судебным, так и внесудебным. Тем не менее, именно государственная политика, которая влияет на перевоспитание и культурные изменения в обществе, является основным способом преодоления этой социальной мазелы (Silva, 2010).

В Бразилии существует совместное сотрудничество ряда государственных учреждений в попытке искоренить эксплуатацию рабского труда, а именно: Национального института колонизации и аграрной реформы (INCRA); Федеральная полиция (PF); Федеральная дорожно-дорожной полиции (PRF); Министерство труда и занятости (MTE) и прокуратура (MP). Важно отметить, что изолированная работа только одного учреждения не является эфффективной. Другим важным способом борьбы с ним является само общество, которое через анонимные жалобы может дать более быстрые ответы на такие проблемы.

Вопреки практике современного рабского труда, важно подчеркнуть, некоторые авторы, такие, как государственное министерство труда и труда юстиции, которая играет очень важную роль, путем репрессий меры, принимая в качестве примера общественные гражданские иски за моральный ущерб, который стремится денежного возмещения.

Важно отметить создание Национального плана по искоренению рабского труда, который был подготовлен Специальным комитетом Совета по защите прав человека (CDDPH), который действует по всей стране. Этот план объединяет организации и органы власти, связанные с этой темой, которые стремятся к созданию и поддержанию прочной государственной политики, под контролем национальных органов или форума, посвященного репрессиям рабского труда.

Другая стратегия борьбы с такой преступностью в Бразилии берет свое начало через Национальную комиссию по искоренению рабского труда (CONATRAE), которая фрормулирует и выполняет инициативы. По данным Oliveira (2011), этот RC: 86628

Ссылка доступа: https://www.nucleodoconhecimento.com.br/социальныенауки/текстильной-промышленности 
орган был создан в августе 2003 года и формируется коллегией, связанной со Специальным секретариатом по правам человека при президенте Республики, который в качестве основной функции следит за осуществлением Национального плана по искоренению рабского труда.

Другой фрормой столкновения является Национальный пакт о ликвидации труда Раб в Бразилии. Эта инициатива основана на международных усилиях под влиянием OIT (Международная организация труда, орган ONU). Вышеупомянутый пакт работает в сотрудничестве с органами государственной инспекции, которые стремятся найти и наказать современный рабский труд. По словам Miranda e Oliveira (2010), эти усилия приносит результаты, получая поддержку от представителей компаний, которые в совокупности означают более $25 \%$ национального PIB.

Одним из способов борьбы с трудом, аналогичным самому известному рабу в Бразилии, является «грязный список». Этот инструмент работает следующим образом: создан Реестр работодателей, который обязывает работников подчиняться условиям, аналогичным условиям рабства. Этот список является механизмом общественной прозрачности бразильского государства, созданным в 2003 году, который стремится раскрыть имена физических или юридических лиц, которые были пойманы с использованием рабского труда (Mattos, 2015).

Вышеупомянутый реестр регулируется Постановлением № 1234 от 2003 года Министерства труда и занятости, которое впоследствии было заменено межведомственным постановлением № 2 от 12 мая 2011 года, документом, в котором говорится о его силе (Campos, 2015). Считается, что эта форма борьбы становится очень важной в борьбе с современным рабским трудом, а также список работодателей, по мнению ONU, эталонная модель в мире.

В том же смысле закон № 14 946/2013 «Грязный список» был создан штатом Сан-Паулу, целью которого является поиск и запретить деятельность компаний, которые имеют в своей производственной цепочке использование работников в условиях, аналогичных рабству. Этот закон был принят по законопроекту № 1034 RC: 86628 Ссылка доступа: https://www.nucleodoconhecimento.com.br/социальныенауки/текстильной-промышленности 
от 2011 года, автором которого является конгрессмен Carlos Bezerra Junior, имея особенность, поскольку он направлен на реальность работников текстильной промышленности paulista (относительно штата São Paulo) (Mattos, 2015).

Форма борьбы, выраженная в этом законе, основана на отмене государственной регистрации налогоплательщиком налога на оборот товаров и услуг (ICMS). Таким образом, работодатель, который прямо или косвенно выигрывает от рабского труда, отозвал свою регистрацию, помимо ограничения законодательством, действующим в отношении субъекта, такое наказание представлено в статье 1 этого закона (Dou, 2013).

Статья 4 Закона No 14946 от 2013 года штата São Paulo, после отмены регистрации ICMS, юридическое лицо,нарушая закон, не может осуществлять деятельность в том же отделении, даже в другом месте, и партнеры не могут открывать другие компании той же деятельности, в течение 10 лет, с момента импичмента (Campos, 2015).

Рабский труд, хотя и отменен на протяжении сотен лет, остается в обществе, вопреки правам человека. Современное рабство, в отличие от старого времени, было основано уже не на собственности господа над рабами, а тем более на бизнесе покупки и продажи рабочих, а скорее на чрезмерном контроле предпринимателя над работником, используя такие средства, как принуждение и coertion, с целью увеличения его прибыли.

Одним из секторов экономики, в которых такая преступная практика присутствует, является текстиль. Существующий в крупных мировых столицах рабский труд больше не является преимущественно сельским и позиционирует себя как городской, особенно на швейных фабриках.

В реальности городского рабского труда большое число людей покидают свои дома, покидая семьи в поисках лучших условий жизни и в конечном итоге подчиняясь практике, аналогичной рабству, главным образом по необходимости, на крупных текстильных фабриках (Campos, 2015).

RC: 86628

Ссылка доступа: https://www.nucleodoconhecimento.com.br/социальныенауки/текстильной-промышленности 
Поэтому текстильная промышленность является одним из великих исследователей современного рабского труда. По данным Mattos (2015), текстильная промышленность напрямую выигрывает от современного рабского труда, тем более что его производство является краткосрочным, и Китай является одним из основных пользователей этого вида рабочей силы, что делает его чрезвычайно конкурентоспособным на этом рынке.

Используя эту ситуацию уязвимости человека, «индустрия моды» использует рабский труд как способ снижения своих производственных издержек. Текстильная промышленность, за счет аутсорсинга своей деятельности, в конечном итоге способствует неустойчивомуутудания условий труда, делегируя свою деятельность мастерским фрормальных или даже самодельных швов.

Эта система эксплуатации рабского труда, используемая текстильной промышленностью, известна как sweating system, которая является наиболее найденной формой современного рабства в городской среде во всем мире. Английский термин, также известный как "пот системы" (наш перевод), относится к рабочим местам, выполняемых в необычных местах, которые в конечном итоге путают с местами жительства и предлагают экстремальные условия труда и несчастной заработной платы (Cristova e Goldschmidt, 2012).

Следует отметить, что основными субъектами, возглавляемыми этими системами, являются иностранцы, как правило, из более слаборазвитых стран, таких, как некоторые страны Азии и Латинской Америки. Ибо, из-за состояния скупости, что они находятся в своих странах, они в конечном итоге привлекает ложные предложения о работе. Таким образом, капиталистический рынок создает условия, в которых компании ищут аутсорсинг как способ снижения издержек и повышения конкурентоспособности. Рабочий по необходимости подвергается работе в условиях, аналогичных рабу, давая место для создания небольших швейных мастерских, которые практикуют эксплуатацию, посредством принудительного и унижающего достоинство труда (Palo Neto, 2008).

RC: 86628

Ссылка доступа: https://www.nucleodoconhecimento.com.br/социальныенауки/текстильной-промышленности 
Условия труда, аналогичные рабу, в которых находятся работники индустрии моды в Бразилии, являются частью современного городского рабского труда, что немного реже, чем в сельской местности, но также является серьезной проблемой.

Эта сеть рабства в городской среде непосредственно связана с иммиграцией иностранцев, поступающих главным образом из более бедных стран Латинской Америки. Труд, который привлекает к работе на фабриках одежды. Этот факт не исключает внутренней торговли самими людьми, которые направляются из внутренних дел Бразилии, из небольших муниципалитетов, в крупные мегаполисы (Mattos, 2015).

Рост этого вида преступности произошел в основном, по словам Santos (2015), в связи с увеличением значимости текстильной промышленности для внутреннего рынка страны в последние десятилетия, в связи с расширением среднего класса и доступом низших классов к кредитным линиям, интенсивно стимулируя потребление (Palo Neto, 2008). В 2012 году промышленность страны создала 1,7 миллиона фрормальных рабочих мест, из которых 733 миллиона сосредоточены в швейной промышленности (Campos, 2015).

Поэтому, поскольку Бразилия имеет текстильной промышленности, имеющих отношение к своей экономике, добавил к простоте дешевой рабочей силы в странах Латинской Америки (соседи) и необходимость стать более конкурентоспособными в условиях внешних меркар, иностранцы стали легкой добычей для реализации производственной системы, упомянутых выше, sweating system.

Sweating system является одной из фрорм аутсорсинга, что крупные бренды найти, чтобы снизить свои производственные затраты, пытаясь освободить себя от трудовых обязанностей.

Эта система имеет такую же характерную, как и рабочие места, которые путаются с местами жительства, в которых трудящиеся работают в плачевных RC: 86628

Ссылка доступа: https://www.nucleodoconhecimento.com.br/социальныенауки/текстильной-промышленности 
условиях, страдают от угнетения, получают мизерную заработную плату, имеют исчерпывающий и нестабильный рабочий день.

Эта фрорма работы, где нет минимума уважения к трудовому законодательству, в котором вознаграждение выплачивается только за производство, также известна как "потовая система" (наш перевод). В Бразилии этот вид работы чаще встречается среди иностранных рабочих (Cristova e Goldschmidt, 2012).

Один из самых значительных случаев в последние годы произошел в 2011 году в городе Американа, в том что было связано с магазином «Zara» в штате São Paulo, в котором прокуратура обнаружила 51 человека (в основном боливийцев), работающих в условиях, аналогичных рабству на швейной фрабрике, поставляющей крупную марку. Рабочие подвергались напряженным поездкам до 14 часов в день, получая двадцать центов за произведенную часть (Cristova and Goldschmidt, 2012).

Другим случаем больших последствий стало участие сети Pernambucanas, которая, даже после расследования в 2010 и 2011 годах, не хотела подписывать с прокуратурой срок корректировки поведения, и против которой был подан иск за эксплуатацию труда (Cristova e Goldschmidt, 2012).

В Бразилии борьба с такого рода практикой в основном проводится государственными учреждениями, такими, как государственное министерство труда, фредеральная полиция, фредеральное правительство и правительства штатов, а также международными организациями, такими, как OІT, которые стремятся посредством надзора и наказания обуздать этот вид бесчеловечной практики, которая затрагивает главным образом латиноамериканских иностранцев, при этом значительное большинство из них прибудут из Боливии , в намерении избежать ужасных условий жизни, которые есть.

По данным Mattos (2015), большинство людей, которые подвергаются ухудшению условий труда в текстильной промышленности в Бразилии, являются боливийцы, которые покидают свою страну из-за нестабильной социальноRC: 86628 Ссылка доступа: https://www.nucleodoconhecimento.com.br/социальныенауки/текстильной-промышленности 
экономической ситуации, коррупции и государственной системы, так как страна имеет одни из худших социальных показателей в южной Америке.

Стремясь получить только прибыль, компании нанимают боливийских иммигрантов и платят им в соответствии с производством, подвергая их низкой заработной плате, подвергая их изнурительным и унижающим достоинство поездкам, которые достигают до 16 часов в день. Они также страдают от принудительного труда, несмотря на ограничение их свободы, из-за долгов, которые рождаются из нерегулярных коллекций, или потому, что они документируются незаконно.

Таким образом, боливийская рабочая сила отвечает сиюминутной потребности текстильного сектора, поскольку они являются одноразовыми, временными и изолированными работниками, не имея социальной защиты, которые адекватно заполняют пустоту дешевых услуг, отступаемых бразильцами.

Бразилия на протяжении десятилетий принимает борьбу с такого рода практикой через союз правительств и неправительственных организаций. И именно через наблюдение были обнаружены и воевали многие случаи боливийцев в условиях, аналогичных рабу. Один из самых удивительных случаев произошел в 2011 году в городе Американа, в штате São Paulo, где министерство труда обнаружило 51 человека, из которых 46 боливийцев, работающих в условиях, аналогичных рабству, унижающим достоинство и бесчеловечным образом в мастерской, которая, в свою очередь, была нанята крупным розничным магазином «Zara». Рабочие работали в среднем 14 часов в день и получали $\mathrm{R} \$$ 0,20 (двадцать центов) за единицу произведенной одежды (Cristova e Goldschmidt, 2012).

Еще одним случаем, который получил много национальных последствий, было участие в крупном розничном магазине "Marisa", который получил 48 уведомлений о нарушении за содержание 16 боливийцев в ситуации современного рабства, в городе São Paulo. Рабочие были представлены на 14часовой ежедневный час, получив только $\mathrm{R} \$ 247,00$ (двести сорок семь реалов). 
Кроме того, на сайте были найдены документы, доказывающие незаконный оборот иммигрантов через границу (Campos, 2015).

Не убегая от большинства других случаев, которые происходят в Бразилии, рабочие обнаружили, в основном боливийских иммигрантов, которые были заманили через обещания занятости и улучшения условий жизни. Однако по прибытии в Бразилию реальность была иной. Они оказались в долговой системе, в основном с участием продуктов питания, транспорта и документации (Mattos, 2015).

\section{ВЫвОды}

Благодаря своей новой одежде современный рабский труд стал невидимым на некоторое время, но усилиями международных организаций и ряда стран он теперь признан и концептуализирован, и его борьба возможна.

Факторы, которые делают возможным совершение этого преступления, даже если в настоящее время, это в основном связано с штативом: безнаказанность, бедность и прибыль.

Положение в условиях нищеты наиболее нуждающихся селения вынуждает их проходить виды работ в нечеловеческих условиях. В случае текстильной промышленности этих работников принуждают швейные мастерские, которые, в свою очередь, предоставляют аутсорсинговые услуги крупным розничным магазинам, характеризующие sweating system производства.

Конкурентоспособность рынка, стремящихся к прибыльности любой ценой, заставляет текстильный сектор подвергать работников шестнадцатичасовому ежедневному, в нездоровых местах и лишенным свободы.

Эти текстильные работники в основном являются иммигрантами из соседних, слаборазвитых стран Латинской Америки. Основной страной, снабжающей 
рабочую силу, является Боливия, которая имеет большое население в нищете, которая стремится к улучшению условий жизни в соседней стране.

Бразилия была одной из первых стран в мире, признавающих этот вид работы, и что совместно с Международной организацией труда (OIT) и правительственными образованиями, стремятся бороться с такой преступной практикой на своей территории.

Таким образом, рабский труд по-прежнему является реальностью в Бразилии и в мире, находя условия для распространения в бразильском текстильном секторе.

\section{ссылки}

ARAÚJO JÚNIOR, F. M. Dano moral decorrente do trabalho em condição análoga à de escravo: âmbito individual e coletivo. Revista do Tribunal Superior do Trabalho, v. 72 , n. 3, p. 87-104, 2006.

AUDI, P. A escravidão não abolida. In: VELLOSO, G. e FAVA, M. N. (Ed.). Trabalho Escravo Contemporâneo: o desafio de superar a negação. São Paulo SP: LTr, 2006.

BALES, K. Gente descartável: A Nova Escravatura na Economia Mundial. Lisboa: Editorial Caminho, 2001.

BRASIL. Lei n. 2.848, de 07 de setembro de 1940. Institui o Código Penal., Brasília DF, 1940. Disponível em: < http://www.planalto.gov.br/ccivil_03/decretolei/Del2848compilado.htm >. Acesso em: 02 de jun. 2018.

. Código penal - Decreto-lei no $2.848 / 1940$. TÉCNICAS, C. D. E. Brasília DF: Senado Federal: 138 p. p. 2017. 
BRITO FILHO, J. C. M. D. Trabalho com redução do homem à condição análoga de escravo e dignidade da pessoa humana. Genesis: revista de direito do trabalho, v. 23, n. 137, p. 673-682, 2004.

CAMPOS, L. R. J. D. 0 trabalho análogo à condição de escravo no setor têxtil brasileiro. 2015. 41p. (Especialização). Universidade Tuiuti do Paraná, Curitiba PR.

COSTA, C. Para que serve a 'lista suja' do trabalho escravo? , 2015. Disponível em: $<$

https://www.bbc.com/portuguese/noticias/2015/04/150402_trabalho_escravo_entend a_cc >. Acesso em: 17 jun. 2018.

CRISTOVA, K. G.; GOLDSCHMIDT, R. O trabalho escravo contemporâneo no Brasil. Anais III Simpósio Internacional de Direito: dimensões materiais e eficaciais dos direitos fundamentais. IIISID. Chapecó SC: 24 p. 2012.

DAMIÃO, D. R. R. Situações análogas ao trabalho escravo: reflexos na ordem econômica e nos direitos fundamentais. São Paulo SP: Letras Jurídicas, 2014.

DOU. LEI № 14.946, DE 28 DE JANEIRO DE 2013. São Paulo SP, 2013. Disponível em:

http://dobuscadireta.imprensaoficial.com.br/default.aspx?DataPublicacao=20130129 \&Caderno=DOE-I\&NumeroPagina $=1$ >. Acesso em: 28 maio 2018.

FAUSTO, B. História do Brasil São Paulo SP: Editora da Universidade de São Paulo, 2004.

GERHARDT, T. E.; SILVEIRA, D. T. Métodos de pesquisa. Porto Alegre RS: Editora da UFRGS, 2009. 120p.

GORENDER, J. O escravismo colonial. São Paulo SP: Ática, 1985.

GRECO, R. Curso de Direito Penal: parte especial. Niterói RJ: Impetus, 2008. 
LIMA, T. C. S. D.; MIOTO, R. C. T. Procedimentos metodológicos na construção do conhecimento científico: a pesquisa bibliográfica. Rev. Katál., v. 10, p. 37-45, 2007.

MARTINEZ, L. Curso de Direito do Trabalho: relações individuais, sindicais e coletivas do trabalho. São Paulo SP: Saraiva, 2015.

MARTINS, S. P. Direito do Trabalho. São Paulo SP: Atlas, 2011.

MATTOS, C. N. S. D. Análise contemporânea do trabalho análogo ao escravo na indústria têxtil. 2015. 56p. (Graduação). Centro Universitário Eurípides de Marília UNIVEM, Marília SP.

MIRANDA, C. C.; OLIVEIRA, L. J. D. Trabalho análogo ao de escravo no brasil: necessidade de efetivação das políticas públicas de valorização do trabalho humano. Revista de Direito Público, v. 5, n. 3, p. 150-170, 2010.

MONTEIRO, L. A. Políticas públicas para erradicação do trabalho escravo contemporâneo no Brasil: Um estudo sobre a dinâmica das relações entre os atores governamentais e não-governamentais. 2011. 184p. (Mestrado). Fundação Getulio Vargas, Rio de Janeiro RJ.

MONTENEGRO, A. T. Reinventando a liberdade: a abolição da escravatura no Brasil. São Paulo SP: Atual, 1997.

MOTA, M. B.; RAMOS, B. P. História das Cavernas ao Terceiro Milênio. São Paulo Sp: Moderna, 1999.

MTE. Quadro geral de operações de fiscalização para erradicação do trabalho escravo - SIT/SRTE - 1995/2010. Brasília DF, 2018. Disponível em: < http://www.mte.gov.br/fisca_trab/quadro_resumo_1995_2010.pdf >. Acesso em: 18 jun. 2018.

NASCIMENTO, A. M. Curso de Direito do Trabalho. São Paulo SP: Saraiva, 2010. 
OLIVEIRA, J. S. D. O trabalho escravo conteporâneo no Brasil. 2011. 50p. (Especialização). Universidade Anhanguera-Uniderp, Fortaleza CE.

PALO NETO, V. Conceito jurídico e combate ao trabalho escravo contemporâneo. São Paulo SP: LTr, 2008. 128p.

PINSKY, J. Escravidão no Brasil. São Paulo SP: Contexto, 1992.

PRADO, A. A. Trabalho escravo hoje. Brasília DF, 2005. Disponível em: < https://www.anamatra.org.br/artigos/863-trabalho-escravo-hoje-09477223427479363 >. Acesso em: 15 jun. 2018.

PRONER, A. L. Neoescravismo: análise Jurídica das Relações de Trabalho. Curitiba PR: Juruá, 2010.

RODRIGUEZ, P. A. D. S. Princípios Constitucionais aplicado ao Direito do Trabalho: Colisão de Princípios nos casos concretos. 2015. 49p. (Especialização). Universidade Federal do Rio Grande do Sul, Porto Alegre RS.

SARAIVA, R. Direito do Trabalho. São Paulo SP: Método, 2012.

SILVA, J. B. D. Trabalho escravo rural no brasil contemporâneo - uma ofensa à dignidade humana. 2009. 45p. (Especialização). Instituto Brasiliense de Direito Público, Brasília DF.

SILVA, M. R. D. Trabalho análogo ao de escravo rural no Brasil do século XXI: novos contornos de um antigo problema. 2010. 280p. (Mestrado). Universidade Federal de Goiás, Goiânia GO.

SIMÓN, S. L.; MELO, L. A. C. D. Direitos humanos fundamentais e trabalho escravo no Brasil. São Paulo SP: LTr, 2007.

SOARES, S. F. Notas estatisticas sobre a producção agricola e carestia dos generos alimenticios no Imperio do Brazil. Rio de Janeiro RJ, 1860. Disponível em: < http://www2.senado.leg.br/bdsf/handle/id/221678 >. Acesso em: 20 jun. 2018.

$\mathrm{RC}: 86628$

Ссылка доступа: https://www.nucleodoconhecimento.com.br/социальныенауки/текстильной-промышленности 
Представлено: Май, 2021.

Утверждено: Май 2021 года. 